Final Technical Report-Award No. DE-FG02-04ER63906-"Promoting Uranium Immobilization by the Activities of Microbial Phosphatases" PI: Patricia Sobecky; co-PI Martial Taillefert

The primary objectives of this research project entitled "Promoting Uranium Immobilization by the Activities of Microbial Phosphatases" were to (i). determine if the phosphatase activities of metal resistant bacteria isolated from contaminated subsurface soils at the Oak Ridge field site (Oak Ridge Reservation, Oak Ridge Tennessee) resulted in solid uranium (U)-phosphate precipitation in both aerobic and anaerobic conditions, (ii). determine the effects of $\mathrm{pH}$ and organophosphate concentration on $U$ solubility and phosphatase activity, (iii). characterize the chemical composition of the $U$ phosphate mineral, (iv). conduct in-depth determinations of phosphate-liberating microbial populations in contaminated subsurface soil slurries and flowthrough reactors using high-density $16 \mathrm{~S}$ DNA microarray analyses, and (v) determine the proportion of U-P minerals precipitated at $\mathrm{pH} 5.5$ and 7.0 in soils from the contaminated subsurface using flow-through reactors. The microarray analyses and mineral precipitation characterizations were conducted in collaboration with DOE-funded investigators at Lawrence Berkeley National Laboratory and the Stanford Synchrotron Radiation Light source.

\title{
Summary/highlights of major results:
}

(1). Demonstrated microbially mediated immobilization of uranium [U(VI)]: The results of this project demonstrated that naturally occurring metal resistant bacteria (i.e., Rahnella sp., Bacillus sp.) isolated from metal- and radionuclide-contaminated soils were able to promote the precipitation and immobilization of uranium from groundwater and soils through their intrinsic metabolic activities. Specifically, the phosphatase activity of naturally occurring soil microorganisms, when grown in the presence of glycerol-2-phosphate (G2P) or glycerol-3phosphate $(\mathrm{G} 3 \mathrm{P})$, demonstrated that incubations at $\mathrm{pH} 5.5$ promoted a greater release of orthophosphate when compared to incubations conducted under unbuffered conditions ( $\mathrm{pH}$ 6.8). Average phosphate concentrations for $\mathrm{pH} 5.5$ and $\mathrm{pH} 6.8$ oxic incubations after 36-days were 5 $\mathrm{mM}$ and $2 \mathrm{mM}$, respectively. PhyloChip analysis (e.g., microbial diversity) of these incubations identified over 1200 OTUs dominated by the phylum Proteobacteria. Soils incubated for 36days under anoxic conditions liberated $0.5 \mathrm{mM}$ phosphate and were able to denitrify over $10 \mathrm{mM}$ nitrate. Flow-through reactor studies indicated that up to $3 \mathrm{mM}$ phosphate can liberated from G2P stimulated soil columns and bulk XANES analysis of these soil columns indicated that uranium was sequestered as a U(VI) phosphate.

(2). Determinations of the chemical composition of $\boldsymbol{U}$ mineral: XANES confirmed that uranium precipitates in aerobic conditions of Rahnella cultures were composed of U(VI). EXAFS identified the uranium phosphate precipitate formed in live incubations as a result of phosphatase activity at $\mathrm{pH} 5.5$ as autunite/meta-autunite and at $\mathrm{pH} 7$ a mixture of autunite/metaautunite and uranyl hydroxide. Synchrotron-based XRD confirmed these findings.

Thermodynamic modeling using MINEQL+ (v. 4.5) predicted the principle mineral phase at $\mathrm{pH}$ 7 as autunite/meta-autunite with uranyl hydroxide comprising only a small percentage of the mineral mixture. In contrast, EXAFS identified uranyl hydroxide as the only mineral phase 
formed at $\mathrm{pH} 7.0$ in chemical control incubations with G3P. The difference in the composition of the uranyl mineral formed in the presence of live cells compared to the mineral formed in chemical controls demonstrates that the precipitation of uranium was driven by biological activities. Thermodynamic modeling of groundwater containing a $1: 5 \mathrm{UO}_{2}{ }^{2+}$ to $\mathrm{PO}_{4}{ }^{3-}$ ratio identified a low solubility range for autunite between $\mathrm{pH} 4$ and 8, even in the presence of high concentrations of sulfate and nitrate. Carbonate, which is prevalent in natural systems, plays an important role in U solubility; however, carbonate should not affect autunite solubility below $\mathrm{pH}$ 8. These findings demonstrate the potential for uranium phosphate biomineralization as an important process in aerobic aquifers below circumneutral $\mathrm{pH}$, where $\mathrm{U}$ is a major contaminant. Rahnella sp. exhibited phosphatase activity at $\mathrm{pH} 5.5$ in both aerobic and anaerobic incubations resulting in the precipitation of U-phosphate. The chemical composition of these precipitates was compared to determine if there was a difference in precipitates formed in the presence and absence of oxygen. XRD, XANES, and EXAFS analyses of the precipitates identified the same mineral formed both aerobically and anaerobically. XANES analysis indicated that all precipitates were of the U(VI) valence state showing that Rahnella sp. did not reduce U. EXAFS analysis is characteristic of autunite-type minerals and XRD patterns identify the minerals formed as chernikovite $\left[\mathrm{H}_{2}\left(\mathrm{UO}_{2}\right)_{2}\left(\mathrm{PO}_{4}\right)_{2}\right]$.

(3). Characterization of $U$ biomineralization in contaminated soils. A series of experiments were conducted during this project to demonstrate microbially-mediated uranium biomineralization in contaminated soils to determine its potential application and feasibility for in situ bioremediation. Plug flow reactors (PFR) loaded with contamined soil were utilized to investigate if: (1) oxic conditions could be maintained in inoculated soil columns, (2) indigenous naturally occurring soil bacteria exhibited phosphatase activity when provided with an organophosphate, and (3) sufficient phosphate was produced to precipitate substantial soluble U(VI). Triplicate PFRs (12-cm length) were filled with homogenized sediment from contamined soils collected at the Oak Ridge study site. Aerated synthetic groundwater ( $\mathrm{pH} 5.5$ and 7.0) amended with $15 \mathrm{mM}$ nitrate as the sole nitrogen source, $20 \mathrm{mM}$ bromide as a tracer, and $10 \mathrm{mM}$ G3P as the sole carbon and phosphorus was pumped through the columns. The PFRs remained oxic throughout the 30-day experiment as indicated by the presence of $\mathrm{O}_{2(\mathrm{aq})}$ and the absence of any reduced species $\left(\mathrm{Fe}^{2+}, \mathrm{Mn}^{2+}, \mathrm{H}_{2} \mathrm{~S}\right)$, but the reactors at pH 5.5 also exhibited some nitrate reduction and transient build up of nitrite. Within 16 hours of G3P addition, $\mathrm{PO}_{4}{ }^{3-}$ increased in all three amended reactor effluents and $\mathrm{PO}_{4}{ }^{3-}$ continued to be released in high concentrations $(>500 \mu \mathrm{M})$ throughout the experiment. Control reactors amended with U(VI) but without G2P did not produce any $\mathrm{PO}_{4}{ }^{3-}$ suggesting that phosphatase activity was below detection in unamended soils. In soil amended with $\mathrm{G} 3 \mathrm{P}>97 \%$ of total $\mathrm{U}\left(200 \mu \mathrm{M} \mathrm{UO}_{2}{ }^{2+}\right.$ added on day 10$)$ was retained compared to $<80 \%$ retention in the U(VI)-amended controls. XAS analyses confirmed the presence of U-phosphate precipitates in the amended soils at both $\mathrm{pH}$ as well as some U(VI) adsorbed to the soils. Chemical extractions corroborated these findings and supported the conclusion that the majority of $U$ is retained as U-P minerals while $U$ is mainly adsorbed onto iron oxide phases in the U-amended control experiments. These findings support the hypothesis that the addition of an organophosphate substrate to contaminated soils will promote microbial phosphatase activity and result in sufficient phosphate accumulation to precipitate uranium phosphate minerals. 


\section{Publications and presentations resulting from the project:}

(1). Sobecky, P.A. and J. Coombs. 2009. Horizontal gene transfer in metal contaminated and radionuclide contaminated soils. In: Horizontal Gene Transfer-Genomes In Flux (Editors; Peter Gogarten, Lorraine Olendzenski and Maria Gogarten), Vol. 52, pp. 435453. Humana Press.

(2). Beazley, M.J., Martinez, R.J., Sobecky, P.A., Webb, S.M., and Taillefert, M. 2009. Nonreductive biomineralization of uranium(VI) phosphate via microbial phosphatase activity in anaerobic conditions. Geomicrobiology Journal 126:431-441.

(3). Martinez, R.J., Beazley, M.J., Wu, C., Hazen, T.C., Andersen, G.L., Webb, S.M., Taillefert, M., Sobecky, P.A. 2009. Microbial phosphatase activity involved in subsurface uranium sequestration. $109^{\text {th }}$ General Meeting Abstracts. American Society for Microbiology, Philadelphia, PA. (Poster Presentation)

(4). Martinez, R.J., Beazley, M.J., Salome, K., Wu, C., Hazen, T.C., Andersen, G.L., Webb, S.M., Taillefert, M., Sobecky, P.A. 2009. Uranium immobilization by the activities of microbial phosphatases. 2009 U.S. DOE ERSP Annual PI Workshop. Lansdowne, VA. (Poster Presentation)

(5). Sobecky, P.A., Martinez, R.J., Beazley, M.J., Webb, S.M., Taillefert, M. 2009. Coprecipitation of metals and actinides mediated by microbial phosphatases. 237th National Meeting. American Chemical Society, Salt Lake City, UT (Invited talk)

(6). Sobecky, P.A., Martinez, R.J., Beazley, M.J., Webb, S.M., Taillefert, M. 2008. Uranium immobilization by the activities of microbial phosphates. 7th International Symposium for Subsurface Microbiology, Shizuoka, Japan (Invited talk)

(7). Sobecky, P.A. 2008. Bioremediation Promoted by Microbial Biomineralization Activities U.S. DOE Radioimaging Workshop, Bethesda, MD. (Invited Plenary talk)

(8). Sobecky, P.A. 2008. Uranium Immobilization by the Activities of Microbial Phosphates. Brookhaven National Laboratory. (Invited talk)

(9). Martinez, R.J., Beazley, M.J., Wu, C., Hazen, T.C., Andersen, G.L., Webb, S.M., Arakaki A.K., Skolnick, J.,Taillefert, M., Sobecky, P.A. 2008. Promoting uranium immobilization by the activities of microbial phosphatases. Frontiers in Multi-Scale Systems Biology (International Launch Conference), Atlanta, GA. (Poster Presentation)

(10). Martinez, R.J., Beazley, M.J., Wu, C., Hazen, T.C., Andersen, G.L., Webb, S.M., Taillefert, M., Sobecky, P.A. 2008. Promoting uranium immobilization by the activities of microbial phosphatases. $108^{\text {th }}$ General Meeting Abstracts. American Society for Microbiology, Boston, MA. (Poster Presentation)

(11). Beasley, M.J., Martinez, R.J., Sobecky, P.A., Webb, S.M., Taillefert, M., 2008. Biomineralization of uranium phosphate from contaminated waste sites. 2008 U.S. DOE ERSP Annual PI Workshop. Lansdowne, VA. (Poster Presentation)

(12). Taillefert, M., Beazley, M. J., Martinez, R. J., Webb, S., Sobecky, P. A. 2008. The role of microbial phosphatases on uranium mobility in the subsurface. 2008 U.S. DOE ERSP Annual PI Workshop. Lansdowne, VA. (Invited talk).

(13) Beazley M. J., 2009. Non reductive biomineralization of uranium(VI) as a result of microbial phosphatase activity. Ph. D. Thesis, Georgia Institute of Technology, 204 p.

(14). Beazley, M.J., R.J. Martinez, P.A. Sobecky, S.M. Webb and M. Taillefert. 2007. Uranium biomineralization as a result of bacterial phosphatase activity: insights from 
bacterial isolates from a contaminated subsurface. Environmental Science and Technology 41:5701-5707.

(15). Martinez, R.J.,* Beazley, M.J.,* Taillefert, M. Arakaki, A.K., Skolnick, J., and P.A. Sobecky ${ }^{\mathbf{c}}$. 2007. Aerobic uranium(VI) bioprecipitation by metal resistant bacteria isolated from radionuclide- and metal-contaminated subsurface soils. Online publication: (Aug. 20, 2007) doi: 10.1111/j.1462-2920.2007.01422.x. Environmental Microbiology published 9(12):3122-3133. 